\title{
PENGARUH MOTIVASI KERJA DAN INSENTIF TERHADAP KINERJA APARATUR PEMERINTAH KECAMATAN AMBULU KABUPATEN JEMBER
}

\author{
RIZC DITYA PURBA TANDRI \\ SASONGKO \\ ZARAH PUSPITANINGTYAS* \\ Program Studi Magister Ilmu Administrasi \\ Fakultas Ilmu Sosial dan Ilmu Politik \\ Universitas Jember \\ *Email: zp.zarahpuspita@gmail.com
}

\begin{abstract}
ABSTRAK
Penelitian ini bertujuan mengetahui dan menjelaskan pengaruh motivasi kerja dan insentif terhadap kinerja aparatur pemerintah kecamatan. Penelitian ini menggunakan desain penelitian kausalitas dan merupakan tipe penelitian hubungan atau asosiatif dengan menggunakan data kuantitatif. Teknik pengumpulan data yang digunakan adalah kuesioner, observasi, wawancara dan dokumentasi.. Populasi dalam penelitian ini adalah seluruh pegawai kecamatan dan desa-desa di Wilayah Kecamatan Ambulu Kabupaten Jember sejumlah 113 orang. Teknik sampling dalam penelitian ini menggunakan sampel 53 orang. Analisis data yang digunakan untuk menjawab hipotesis yang diajukan adalah regresi linier berganda dengan bantuan paket software SPSS 16 For Windows. Hasil penelitian menunjukkan bahwa secara parsial motivasi kerja berpengaruh terhadap kinerja aparatur pemerintah kecamatan, sedangkan insentif tidak berpengaruh terhadap kinerja aparatur pemerintah kecamatan.
\end{abstract}

Kata Kunci: Motivasi Kerja, Insentif, Kinerja. 


\section{PENDAHULUAN}

Terselenggaranya Good Governance merupakan persyaratan bagi setiap pemerintahan untuk mewujudkan aspirasi masyarakat dalam mencapai tujuan serta cita-cita bangsa bernegara. Kedudukan dan peranan pegawai/karyawan sebagai Aparatur Sipil Negara (ASN) sangatlah penting dalam kelancaran pemerintahan, pelayanan publik, dan pembangunan nasional.

Gambaran mengenai kinerja aparatur pemerintah di saat masih jauh dari cita-cita yang dicanangkan oleh reformasi birokrasi. Indonesia masih menghadapi hambatan dalam rendahnya kinerja pelayanan birokrasi dan masih tingginya angka korupsi. Hal ini tergambar dari beberapa laporan kinerja pemerintahan seperti The Global Competitiveness Report 2014-2015 (World Economic Forum, 2015) dimana Indonesia menempati peringkat 37 dari 140 negara, dan laporan Bank Dunia melalui Worlwide Governance Indicators yang menunjukkan bahwa efektivitas pemerintahan (Government Effectiveness) Indonesia masih sangat rendah, dengan nilai indeks di tahun 2014 adalah -0,01. Selain itu Indeks Persepsi Korupsi (The Corruption Perceptions Index) Indonesia berdasarkan data dari Transparency International juga masih rendah pada nilai indeks 34 (dari nilai indeks bersih korupsi 100) dan berada pada ranking 107 dari 175 negara pada tahun 2014. Hal ini tentunya menjadi kendala karena pembangunan nasional dalam era persaingan global menuntut adanya birokrasi yang efisien, berkualitas, transparan, dan akuntabel, terutama terhadap prospek bidang investasi di Indonesia.

Kinerja organisasi pemerintah di sektor publik menjadi topik berbagai kajian di bidang sumber daya manusia baik yang diselenggarakan oleh intstitusi pemerintahan, praktisi, maupun akademisi. Kinerja dalam organisasi dianggap menjadi salah satu tolak ukur dalam pencapaian tujuan organisasi. Kinerja adalah hasil atau tingkat keberhasilan seseorang secara keseluruhan selama periode tertentu dalam melaksanakan tugas dibandingkan dengan berbagai 
kemungkinan, seperti standar hasil kerja, target atau sasaran maupun kriteria yang ditentukan terlebih dahulu dan telah disepakati bersama (Rivai dan Basri, 2005).

Kinerja dalam menjalankan fungsinya tidak berdiri sendiri, tetapi berhubungan dengan kemampuan dan motivasi kerja. Oleh karena itu menurut Davis dalam Mangkunegara, (2007), ada dua faktor utama yang mempengaruhi kinerja individu yakni kemampuan (ability), dan motivasi kerja (motivation) individu tersebut. Kemampuan individual tergantung dari tingkat pengetahuan (knowledge) yang dimiliki, latar belakang pendidikan, dan keterampilan (skill) yang dikuasai. Sedangkan motivasi kerja individual tergantung sikap (attitude) sebagai motivasi dasar dan lingkungan yang mempengaruhi motivasi tersebut.

Motivasi kerja terkait dengan segala yang diketahui manusia tentang dirinya maupun lingkungannya. Hal ini diperoleh manusia melalui panca indra melalui rangkaian-rangkaian pengalaman manusia itu sendiri. Dengan motivasi kerja yang tinggi maka manusia akan dapat menyelesaikan berbagai macam permasalahan yang dihadapinya sehingga motivasi itu memiliki arti yang sangat penting dalam kehidupan manusia.

Hasil penelitian Mc. Clelland dalam Supiyanto, (2015) menunjukkan bahwa motivasi berhasil memprediksi kinerja atau prestasi kerja individu dalam pekerjaan. Motivasi terkait dengan peran sumber daya manusia dalam organisasi mempunyai arti yang sama pentingnya dengan pekerjaan itu sendiri, mengingat pentingnya peran sumber daya danusia dalam organisasi. Dengan motivasi yang tinggi yang dimiliki oleh sumber daya manusia dalam suatu organisasi tentu hal ini akan menentukan kualitas sumber daya manusia yang dimiliki yang pada akhirnya akan menentukan kualitas kompetitif organisasi itu sendiri.

Insentif sebagai sarana motivasi yang mendorong para pegawai untuk bekerja dengan kemampuan yang optimal, yang dimaksudkan sebagai pendapatan ekstra di luar gaji atau upah yang telah ditentukan. 
Pemberian insentif dimaksudkan agar dapat memenuhi kebutuhan para pegawai dan keluarga mereka. Menurut Mangkunegara (2009), mengemukakan bahwa insentif adalah suatu bentuk motivasi yang dinyatakan dalam bentuk uang atas dasar kinerja yang tinggi dan juga merupakan rasa pengakuan dari pihak organisasi terhadap kinerja karyawan dan kontribusi terhadap organisasi. bahwa insentif merupakan penghargaan dalam bentuk uang yang diberikan oleh suatu organisasi atau tempat bekerja kepada karyawannya atas dasar prestasi kerja yang tinggi atau bekerja melampaui standar yang telah ditentukan. Oleh karenanya insentif dapat menciptakan dorongan pada seseorang agar mau bekerja dengan baik dan agar lebih dapat mencapai tingkat kinerja yang lebih tinggi sehingga dapat membangkitkan gairah kerja dan motivasi seorang pegawai, jadi seseorang mau bekerja dengan baik apabila dalam dirinya terdapat motivasi yang kuat.

ASN diharapkan mempunyai motivasi kerja yang tinggi bekerja dengan disiplin dalam melayani masyarakat yang membutuhkan. Pegawai yang memiliki motivasi yang tinggi akan lebih patuh dengan peraturan, perintah, mempergunakan dan merawat alat kerja dengan baik, tepat waktu, menghindari absen. Namun kenyataannya untuk memiliki sumber daya manusia yang berkualitas dan berpartisipasi tinggi bukanlah hal yang mudah. Hal tersebut berkaitan dengan sikap mental negatif yang dimiliki pegawai pemerintah. Mendukung asumsi tersebut McGregor dalam Robbins, (2008) mengemukakan pada dasarnya setiap manusia suka akan kebebasan dan tidak mau diperintah, kurang suka memikul tanggungjawab, tidak mau bekerjasama, suka mementingkan diri sendiri, mau bekerja yang ringan dengan penghasilan yang besar, seringnya pegawai melakukan pelanggaran misalnya, malas mengikuti rapat, terlambat datang di tempat kerja, atau menunda-nunda pekerjaan, kesemuanya mengarah pada persepsi kinerja organisasi yang rendah. 
Motivasi kerja yang tinggi dalam organisasi dapat menimbulkan perilaku positif terhadap organisasi kerja dan memiliki andil terhadap kinerja pegawai. Memotivasi pegawai secara terus menerus akan mampu meningkatkan kualitas kinerja pegawai. Dalam suatu organisasi, memotivasi aparat dianggap sebagai salah satu tugas yang paling sulit dilakukan baik kepada aparat dalam jabatan manajerial maupun dalam jabatan non manajerial agar mereka dapat melaksanakan pekerjaannya sesuai dengan cara yang menyebabkan bahwa standar-standar hasil pekerjaan yang diekspektasi dapat dilampaui.

Hasil penelitian Kusuma dkk (2015) menyatakan bahwa terdapat pengaruh positif insentif terhadap motivasi dan kinerja pegawai. Mengacu pada hasil tersebut, pimpinan hendaknya dapat terus meningkatkan motivasi kerja kepada pegawai. Kondisi ini mencerminkan bahwa tekad yang mencerminkan kemauan bekerja keras dan fokus pada tujuan organisasi merupakan faktor pembentuk dorongan yang utama sehingga dalam upaya meningkatkan kinerja pegawai, peningkatan tekad ini perlu mendapat prioritas oleh pimpinan. Temuan yang sama diperoleh dari penelitian Khairati, Rusda, (2013), yang menyatakan bahwa motivasi kerja berpengaruh positif signifikan terhadap kinerja karyawan, sehingga jika motivasi kerja dalam organisasi tinggi maka kinerja karyawan juga tinggi dan sebaliknya jika motivasi kerja dalam organisasi rendah maka kinerja karyawan juga rendah.

Berdasarkan kutipan-kutipan dari beberapa jurnal di atas, bisa dikatakan bahwa motivasi kerja dan insentif merupakan faktor yang dapat mengarah pada pencapaian kinerja pegawai. Seorang pegawai yang memiliki motivasi yang tinggi seperti pengetahuan, ketrampilan, kemampuan, dan sikap yang sesuai dengan jabatan yang diembannya selalu terdorong untuk bekerja secara efektif, efisien dan produktif. Hal ini terjadi karena dengan motivasi yang dimiliki pegawai bersangkutan semakin mampu untuk melaksanakan tugas-tugas yang dibebankan kepadanya. Insentif yang diberikan 
organisasi kepada pegawai biasanya akan meningkatkan kinerja yang tinggi dan sekaligus dapat menurunkan tingkat absensi dan sebaliknya jika seorang pegawai memiliki kinerja juga rendah, maka pegawai tersebut tidak akan mendapatkan insentif. Pegawai yang akan memiliki motivasi kerja yang tinggi sedikit kemungkinan untuk mereka terlibat dalam hal yang dapat merugikan organisasi karena memiliki rasa loyalitas yang tinggi

\section{TINJAUAN PUSTAKA}

\subsection{Motivasi Kerja}

Gray dan Starke dalam Winardi, (2001) mengemukakan definisi sebagai berikut "Motivasi adalah hasil proses-proses, yang bersifat internal atau eksternal bagi seseorang individu, yang menimbulkan sikap antusias dan persistensi untuk mengikuti arah tindakan-tindakan tertentu. Selanjutnya teori motivasi yang digunakan dalam penelitian ini adalah teori Mc. Clelland dalam Thoha (1999) ada tiga kebutuhan yaitu; (1) Kebutuhan akan prestasi, maksudnya rasa tanggung jawab yang tinggi, cenderung menetapkan dan selanjutnya dengan loyalitas yang tinggi, pegawai akan menunjukkan kinerja lebih baik. Mengacu pada argumen tersebut, penelitian ini memfokuskan pada motivasi kerja dan insentif serta pengaruhnya terhadap kinerja pegawai.m Berdasarkan uraian di atas penelitian ini bertujuan untuk mengkaji pengaruh motivasi kerja dan insentif terhadap kinerja pegawai.

tingkat kesulitan tugas yang moderat dan menghitung resikonya dan memiliki keinginan yang kuat untuk memperoleh umpan balik atau tanggapan atas pelaksanaan atas tugasnya; (2) Kebutuhan akan afiliasi, maksudnya adalah merupakan suatu keinginan untuk melakukan hubungan bersahabat dan hangat dengan orang lain; dan (3) Kebutuhan akan kekuasaan, maksudnya adalah kebutuhan untuk mempengaruhi dan mengendalikan orang lain dan bertanggung jawab kepadanya. 


\subsection{Insentif}

Menurut pendapat-pendapat para ahli dapat penulis simpulkan bahwa terdapat kesamaan, bahwa insentif merupakan penghargaan dalam bentuk uang yang diberikan oleh suatu organisasi atau tempat bekerja kepada karyawannya atas dasar prestasi kerja yang tinggi atau bekerja melampaui standar yang telah ditentukan. Oleh karenanya insentif dapat menciptakan dorongan pada seseorang agar mau bekerja dengan baik dan agar lebih dapat mencapai tingkat kinerja yang lebih tinggi sehingga dapat membangkitkan gairah kerja dan motivasi seorang pegawai, jadi seseorang mau bekerja dengan baik apabila dalam dirinya terdapat motivasi yang kuat.

Dari beberapa teori insentif tersebut diatas yang digunakan dalam penelitian ini adalah teori insentif dari Hasibuan (2001), yang menyatakan lima aspek yang digunakan untuk mengukur insentif, yaitu sebagai berikut; (1) Kinerja; (2)
Lama kerja
(3)Senioritas;
Kebutuhan; (5) Keadilan dan kelayakan.

\subsection{Kinerja}

Istilah kinerja sering digunakan untuk menyebut prestasi atau tingkat keberhasilan individu maupun kelompok individu. Kinerja bisa diketahui hanya jika individu atau kelompok invidu tersebut mempunyai kriteria keberhasilan yang telah ditetapkan. Kriteria keberhasilan ini berupa tujuan-tujuan atau target-target tertentu yang hendak dicapai.

Milner dalam Sutrisno (2011), mengemukakan ada lima aspek yang digunakan untuk mengukur dari kinerja, yaitu sebagai berikut: (1) Kualitas, kualitas kerja diukur dari persepsi karyawan terhadap kualitas pekerjaan yang dihasilkan serta kesempurnaan tugas terhadap keterampilan dan kemampuan karyawan; (2) Kuantitas, merupakan jumlah yang dihasilkan dinyatakan dalam istilah seperti jumlah unit, jumlah siklus aktivitas yang diselesaikan; (3) Ketepatan waktu, erupakan tingkat aktivitas diselesaikan pada awal waktu yang dinyatakan, dilihat dari sudut koordinasi dengan hasil output serta memaksimalkan waktu yang tersedia 
untuk aktivitas lain; (4) Efektivitas, merupakan tingkat penggunaan sumber daya organisasi (tenaga, uang, teknologi, bahan baku) dimaksimalkan dengan maksud menaikkan hasil dari setiap unit dalam penggunaan sumber daya; (5) Kemandirian, merupakan tingkat seorang karyawan yang nantinya akan dapat menjalankan fungsi kerja dan komitmen kerja.

\subsection{Organisasi}

Organisasi menurut Stoner (2012) adalah suatu pola hubunganhubungan orang-orang di bawah pengarahan manajer (pimpinan) untuk mengejar tujuan bersama. Selanjutnya organisasi menurut Bernard (2010) merupakan suatu sistem aktivitas kerja sama yang dilakukan oleh dua orang atau lebih. Dari pengertian tersebut dapat disimpulkan bahwa organisasi merupakan sekumpulan orang-orang yang disusun dalam kelompokkelompok, yang bekerjasama untuk mencapai tujuan bersama, dan atau organisasi adalah sistem kerjasama antara dua orang atau lebih, atau organisasi adalah setiap bentuk kerjasama untuk pencapaian tujuan bersama, organisasi adalah struktur pembagian kerja dan struktur tata hubungan kerja antara sekelompok orang pemegang posisi yang bekerjasama secara tertentu untuk bersama-sama mencapai tujuan tertentu.

\subsection{Hubungan Antar Variabel}

\section{Hubungan Motivasi Kerja dengan Kinerja Pegawai}

Menurut Mangkunegara (2000) yang mencuplik dari Mc. Cellend seseorang yang mempunyai kinerja maksimal jika memiliki motif yang tinggi, motif yang dimiliki seorang harus ada dalam diri sendiri dan lingkungan kerja. Selanjutnya Gibson yang dikuti oleh Notoadmodjo (2009) menyatakan bahwa faktor-faktor yang mempengaruhi perilaku dan kinerja adalah: (1) Faktor individu (internal) meliputi pemahaman terhadap pekerjaannya, pengalaman kerja, latar belakang keluarga, tingkat sosial ekonomi, dan faktor demografi (umur, jenis kelamin, 
etnis dan sebagainya; (2) Faktor organisasi (eksternal) meliputi sumber daya manusia, kepemimpinan, desain pekerjaan dan struktur organisasi; dan (3) Faktor psikologis, meliputi persepsi terhadap pekerjaan, sikap terhadap pekerjaan, motivasi dari dalam diri individu masing-masing kepribadian. Dari dua pendapat pakar tersebut diatas dapat disimpulkan bahwa hubungan motivasi kerja dengan kinerja adalah sangat erat dan kuat, karena menyangkut pada diri pribadi masing-masing, dengan kata lain baik motivasi kerja maupun kinerja ada dalam pribadi setiap pegawai atau karyawan. Kinerja dan keefektifan pegawai dalam melaksanakan tugas sangat ditentukan oleh motivasi kerja yang disyaratkan pada bidang pekerjaan tersebut. Motivasi kerja berpengaruh terhadap kinerja pegawai. Seorang pegawai yang memiliki motivasi yang tinggi seperti pengetahuan, ketrampilan, kemampuan, dan sikap yang sesuai dengan jabatan yang diembannya selalu terdorong untuk bekerja secara efektif, efisien dan produktif. Hal ini terjadi karena dengan motivasi yang dimiliki pegawai bersangkutan semakin mampu untuk melaksanakan tugas-tugas yang dibebankan kepadanya. Setiap sifat perorangan yang dapat diukur atau dihitung dengan jelas dan dapat ditunjukkan untuk membedakan secara jelas seorang perilaku unggul dari seorang perilaku efektif dari seorang pelaku yang tidak efektif. Dengan adanya motivasi yang akan menghasilkan kinerja yang baik pada pegawai. Terkait hal ini terdapat hubungan yang positif antar motivasi dan kinerja pegawai dalam melakukan suatu pekerjaan.

$\mathrm{H}_{1}$ : Motivasi kerja berpengaruh terhadap kinerja pegawai.

\section{Hubungan Insentif dengan} Kinerja Pegawai

Heidjrachman

mengemukakan insentif merupakan daya tarik yang 
menyebabkan seseorang melakukan sesuatu karena bisa mendapatkan imbalan yang memuaskan kebutuhan. Hubungan yang paling jelas antara kompensasi dan prestasi kerja adalah melalui sistem insentif seperti yang dikemukakan Handoko (1998) menyatakan sistem insentif pada umumnya digunakan untuk menggambarkan rencanarencana pembayaran upah yang dikaitkan secara langsung atau tidak langsung dengan berbagai standar produktivitas/kerja karyawan atau profitabilitas organisasi atau kedua kreteria tersebut. Oleh karena itu, para karyawan yang bekerja dibawah sistem insentif finansial berarti prestasi kerja mereka menentukan, secara keseluruhan atau sebagian penghasilan mereka. Dari pendapat tersebut diatas dapat disimpulkan bahwa dalam memberikan insentif organisasi harus mengetahui kebutuhan karyawan masingmasing. Dengan adanya kebutuhan, seseorang akan termotivasi melakukan pekerjaan, ini berarti dapat membantu dalam upaya memenuhi kebutuhannya. Apabila karyawan merasa kebutuhannya dapat terpenuhi dalam melakukan suatu pekerjaan, maka ia dapat termotivasi untuk bekerja lebih baik dan secara otomatis berarti kinerjanya meningkat. Pada hakekatnya insentif dapat mendorong karyawan bekerja lebih baik dengan memanfaatkan unsur-unsur kerja yang lebih optimal, karena terdorong keinginan untuk memperoleh insentif yang lebih tinggi. Hal ini dapat diperoleh apabila karyawan memenuhi target yang ditetapkan organisasi.

$\mathrm{H}_{2}$ : Insentif berpengaruh terhadap kinerja pegawai. 


\section{METODE PENELITIAN}

1. Tipe Penelitian

Metode penelitian ini yang digunakan dalam penelitian ini adalah menggunakan penelitian survei. Penelitian ini menggunakan desain penelitian kausalitas.

2. Definisi Operasional Variabel

Dalam penelitian ini variabel bebasnya adalah motivasi kerja (X1) dan insentif (X2) serta variabel terikatnya adalah kinerja (Y).

3. Sumber dan Jenis Data

Di dalam melaksanakan penelitian ini sumber data primer yang penulis ambil berasal dari wawancara, observasi, dan kuesioner. Sumber data sekunder adalah data kedua setelah data primer (tidak diperoleh secara langsung), yang dalam penelitian ini penulis peroleh dari dokumentasi yang telah tersedia dan studi pustaka sebagai pelengkap data.

4. Teknik Pengumpulan Data
Penelitian ini menggunakan beberapa teknik pengumpulan data yaitu: kuesioner, observasi, wawancara, studi kepustakaan, dan dokumentasi.

5. Teknik Analisis Data

Mengenai analisis data yang digunakan oleh penulis adalah analisis kuantitatif, yaitu meyakinkan kebenaran dengan menggunakan metode statistik. Data yang telah dikumpulkan dianalisis dengan menggunakan alat analisis statistik yakni analisis regresi linear berganda (multiple linear regression analysis). $\mathrm{Y}=\alpha+\beta 1 \mathrm{X} 1+\beta 2 \mathrm{X} 2+\mathrm{e}$

Keterangan:

$\mathrm{Y}=$ Kinerja Pegawai

$\alpha=$ Konstanta

$\beta 1-2=$ Koefisien Regresi

$\mathrm{X} 1=$ Motivasi kerja

$\mathrm{X} 2=$ Insentif

e $=$ Error 


\section{HASIL PENELITIAN DAN PEMBAHASAN}

4.1 Hasil Analisis Regresi Linier Berganda
Berdasarkan pengujian diperoleh hasil yang dapat disajikan dalam tabel berikut.

Tabel 1. Hasil Analisis Regresi Linier Berganda

\begin{tabular}{lrrrl}
\hline \multicolumn{1}{c}{ Variabel } & $\begin{array}{c}\text { Koef. } \\
\text { Regresi }\end{array}$ & $\mathbf{t}_{\text {hitung }}$ & Sig. & Keterangan \\
\hline Konstanta & 21,220 & 3,860 & 0,000 & - \\
Motivasi & 0,962 & 6,194 & 0,000 & Signifikan \\
Insentif. & 0,330 & 1,558 & 0,126 & Tidak signif. \\
& & & & 0,609 \\
& R Square & & 38,920 \\
& F $_{\text {hitung }}$ & & 0,000 \\
& $\mathrm{~F}_{\text {sig }}$ & & 53 \\
\hline
\end{tabular}

Sumber: Data diolah tahun 2017

Berdasarkan Tabel 1 diperoleh persamaan regresi sebagai berikut:

$$
\mathrm{Y}=21,220+0,962 \mathrm{X} 1+
$$
$0,330 \times 2$

$$
\text { Kinerja }=21,220+0,962
$$

motivasi $+0,330$ insentif

Hal ini dapat diartikan bahwa:

a. Konstanta 21,220 dapat diartikan bahwa tanpa dipengaruhi oleh segala variabel maka variabel kinerja sudah mempunyai besaran senilai 21,220 .

b. Konstanta 0,962 yang mendampingi $\mathrm{X}_{1}$ dapat diartikan bahwa dengan peningkatan 1 satuan variabel motivasi maka akan mengakibatkan meningkatnya kinerja sebesar 0,962 satuan.

c. Konstanta 0,330 yang mendampingi $\mathrm{X}_{2}$ dapat diartikan bahwa dengan peningkatan 1 satuan variabel insentif maka akan mengakibatkan meningkatnya kinerja sebesar 0,330 satuan.

\subsection{Koefisien}

Determinasi

\section{Berganda $\left(\mathbf{R}^{\mathbf{2}}\right)$}

Dari hasil analisa SPSS Tabel 1 menunjukkan bahwa determinasi yang ditunjukkan dengan R Square mempunyai angka 0,609. Hal ini dapat diartikan bahwa motivasi dan insentif berpengaruh sebesar $60,9 \%$ terhadap kinerja. Sementara 
Adjusted R Square menunjukkan angka 0,593 yang dapat diartikan bahwa kinerja dipengaruhi sebesar $40.7 \%$ oleh faktor-faktor lain diluar penelitian. Faktor-faktor lain tersebut dapat berupa (kompetensi, komitmen organisasi, budaya organisasi, dan lain-lain).

\subsection{Pengujian Secara Parsial (Uji}

t)

Berdasarkan Tabel 1 dapat diketahui besarnya pengaruh masingmasing variabel bebas terhadap variabel terikat sebagai berikut:

1. Pengaruh variabel motivasi (X1) terhadap kinerja pegawai (Y)

Hasil analisis data menunjukkan bahwa $\mathrm{t}$ hitung untuk motivasi sebesar 6,194 yang lebih besar dari 2,006 yang merupakan besarnya $t$ tabel dengan 53 responden sampel serta $\alpha \quad 0,025$ yaitu tingkat kesalahan 5\%. Hal ini dapat diartikan bahwa menerima $\mathrm{Ha}$ dan menolak H0. Atau dapat dikatakan bahwa motivasi berpengaruh terhadap kinerja. Apalagi dengan nilai signifikansi sebesar 0,000 yang kurang dari derajat kesalahan sebesar 5\% atau 0,05 . Hal ini dapat diartikan bahwa motivasi berpengaruh secara signifikan terhadap kinerja.

2. Pengaruh variabel insentif (X2) terhadap kinerja pegawai (Y)

Hasil analisis data menunjukkan bahwa $t$ hitung untuk insentif sebesar 1,558 yang lebih kecil dari 2,006 yang merupakan besarnya $t$ tabel dengan 53 responden sampel serta $\alpha 0,025$ yaitu tingkat kesalahan 5\%. Hal ini dapat diartikan bahwa menerima $\mathrm{HO}$ dan menolak Ha. Atau dapat dikatakan bahwa insentif tidak berpengaruh terhadap kinerja. Apalagi dengan nilai signifikansi sebesar 0,126 yang lebih dari derajat kesalahan sebesar $5 \%$ atau 0,05 . Hal ini dapat diartikan bahwa insentif tidak berpengaruh secara signifikan terhadap kinerja. 


\subsection{Pembahasan}

\section{Pengaruh Motivasi Kerja terhadap Kinerja Pegawai}

Hasil pengujian dan analisis data menunjukkan motivasi berpengaruh signifikan dan positif. Artinya apabila nilai variabel motivasi (X1) mengalami kenaikan maka nilai variabel kinerja organisasi (Y) juga akan mengalami kenaikan. Berdasarkan hasil kuesioner dari Aparatur Pemerintahan Kecamatan Ambulu di Kabupaten Jember rata rata distribusi jawaban responden berada pada kategori setuju berkaitan dengan motivasi sebesar 6,194. Hal tersebut memiliki arti bahwa semakin baik motivasi dalam pemerintahan maka akan meningkatkan kinerja pemerintahan. Variabel motivasi dalam penelitian ini diukur melalui tiga indikator yaitu kebutuhan akan prestasi, kebutuhan akan afiliasi, dan kebutuhan akan kekuasaan. Indikator tersebut merupakan suatu faktor yang akan mempengaruhi kinerja

pemerintahan.

Jika ketiga indikator motivasi diurutkan dari yang memberikan pengaruh terbesar pada kinerja pemerintahan, maka indikator yang memiliki pengaruh terbesar dalam katagori jawaban baik adalah kebutuhan akan prestasi dengan nilai skor 55,85\%. Dengan presentase skor yang berbeda tiap itemnya. Jika diurutkan pada pernyataan yang paling tinggi yaitu pada bagaimana respon masyarakat terhadap pelayanan kepada masyarakat. Hal ini berarti bahwa jika pemberian motivasi yang baik maka diharapkan pelayanan terhadap masyarakat semakin baik.

Indikator kebutuhan akan afiliasi mempunyai nilai skor $45,29 \%$ pernyataan yang paling tinggi yaitu pada pernyataan pekerjaan sesuai harapan masyarakat. Pernyataan ini berarti bahwa pekerjaaan yang dilakukan Aparatur Kecamatan dinilai oleh masyarakat. 


\begin{abstract}
Selanjutnya indikator kebutuhan akan kekuasaaan dengan nilai skor 39,63\%. urutan pernyataan yang paling banyak menjawab dalam kategori baik yaitu penguasaan peralatan yang ada di Pemerintahan Kecamatan. Pernyataan ini berarti semakin banyak peralatan yang dikuasai maka semakin baik pula kinerja Aparatur Pemerintahan.
\end{abstract}

\section{Pengaruh}

Insentif

\section{terhadap Kinerja Pegawai}

Hasil pengujian dan analisis data menunjukkan insentif tidak berpengaruh signifikan dan negatif. Artinya apabila nilai variabel insentif

mengalami penurunan maka nilai variabel kinerja aparatur pemerintahan (Y) juga akan mengalami penurunan. Berdasarkan hasil kuesioner dari Aparatur Pemerintahan Kecamatan Ambulu di Kabupaten Jember rata rata distribusi jawaban responden berada pada kategori sedang berkaitan dengan insentif sebesar Ha 1,558, yang memiliki arti bahwa semakin tinggi nilai variabel insentif dalam pemerintahan maka nilai variabel kinerja pemerintahan cenderung sedang atau konstan. Variabel insentif dalam penelitian ini diukur melalui lima indikator yaitu kinerja, lama bekerja, senioritas, kebutuhan hidup dan keadilan atau kelayakan. Indikator tersebut merupakan suatu faktor yang akan mempengaruhi kinerja pemerintahan.

Jika kelima indikator insentif diurutkan dari kategori sangat buruk atau yang tidak memberikan pengaruh terbesar pada kinerja pemerintahan, maka indikator yang memiliki pengaruh terbesar dalam katagori jawaban sangat buruk adalah kinerja dengan nilai skor $83,00 \%$, dengan presentase skor yang berbeda tiap itemnya. Jika diurutkan pada pernyataan yang paling tinggi yaitu pada Standart Operational Procedure (SOP) dalam melakukan pelayanan terhadap masyarakat. Hal ini 
berarti bahwa pemberian insentif masih belum mampu memaksimalkan kinerja Aparatur Pemerintahan sesuai SOP.

Indikator selanjutnya yaitu lama bekerja mempunyai nilai skor 26,42 \%, dengan pernyataan kategori sangat buruk yaitu pemberian insenif antara yang sudah lama bekerja dengan yang baru tidak seimbang. Pernyataan ini berarti bahwa pemberian insentif kurang merata antara aparatur yang bekerja lama dengan yang baru bekerja. Indikator senioritas dengan nilai skor 7,55 \%, dengan menjawab dalam katagori sangat buruk yaitu pernyataan mengenai pengalaman dalam bekerja.

\section{KESIMPULAN DAN SARAN}

\subsection{Kesimpulan}

Berdasarkan analisis data dan pembahasan tersebut diatas maka dapat disimpulkan oleh peneliti sebagai berikut:

1. Motivasi kerja berpengaruh terhadap kinerja. Hal ini bisa
Pernyataan ini berarti semakin banyak pengalaman dalam bekerja semakin besar berpeluang mendapat insentif. Indikator kebutuhan hidup dengan nilai skor $1,88 \%$, dalam kategori sangat buruk yaitu mengenai pemberian insentif sebagai kebutuhan sehari-hari. Pernyataan ini berarti pemberian insentif dipandang sebagai kebutuhan sehari-hari. Indikator keadilan dan kelayakan dengan nilai skor $11,32 \%$ dalam kategori pernyataan sangat buruk yakni mengenai pemerataan insentif bagi senior dengan junior atau yang baru bekerja. Penyataan ini berarti insentif yang diterima senior berbeda dengan junior atau yang baru bekerja. 
nilai kinerja akan naik secara signifikan.

2. Insentif tidak berpengaruh terhadap kinerja. Hal ini bisa dibuktikan dari hasil regresi berganda dari jawaban responden yang menunjukkan pengaruh yang negatif antara insentif dengan kinerja yang artinya apabila nilai insentif naik maka nilai kinerja cenderung konstan atau turun.

3. Adapun beberapa alasan mengapa insentif tidak berpengaruh dalam kinerja Aparatur Pemerintahan Ambulu Kabupaten Jember antara lain:

a. Pemberian insentif tidak diberikan setiap harinya atau tidak rutin diberikan.

b. Insentif diberikan hanya pada saat tertentu dan di waktu yang telah ditentukan.

c. Pemberian insentif hanya diberikan pada orangorang yang telah ditentukan oleh pimpinan. d. Insentif didalam budaya organisasi publik tidak mengutamakan mencari keuntungan melainkan public service atau pelayanan terhadap masyarakat.

e. Pembagian insentif yang belum merata antara yang diterima oleh yang lama bekerja dengan yang baru bekerja.

\subsection{Saran}

Berdasarkan kesimpulan tersebut di atas, saran yang penulis sampaikan sebagai berikut:

1. Motivasi kerja perlu ditingkatkan terus oleh pimpinan, agar pekerjaan yang diharapkan oleh organisasi dapat tercapai dengan baik.

2. Dalam memotivasi kerja diharapkan para Aparatur Pemerintahan bisa memaksimalkan kinerjanya baik dari segi pelayanan masyarakat maupun dari kinerja organisasi. 
3. Insentif yang diberikan kepada bawahan harus merata, jangan hanya pegawai itu saja yang mendapatkan insentif.

\section{DAFTAR PUSTAKA}

Arikunto, Suharsimi. 2006. Prosedur Penelitian Suatu Pendekatan Praktek. Jakarta: PT. Rineka Cipta.

As'ad, Moh. 2003. Psikologi Industri. Yogyakarta: Lyberty.

Anoraga dan Suyati, 1995, Psikologi Industri, PT. Dunia Pustaka Jaya: Jakarta.

Handoko, Hani, 2008. Manajemen Personalia Sumber Daya Manusia. Edisi Kedua, Yogyakarta: Penerbit BPFE.

Handoko, Hani, 1998, Manajemen Suatu Pengantar, Jakarta: Ghalia.

Hasibuan, Malayu, 1999, Organisasi dan Motivasi, Bandung: Bumi Aksara.

Hasibuan, Malayu. 2001. Manajemen Sumber Daya Manusia. Jakarta: Gunung Agung.

Heidjrachman, 2000, Manajemen Personalia, Ed. 4, Yogyakarta: BPFE UGM.

Koentjaraningrat. 2007. MetodeMetode Penelitian Masyarakat. Jakarta: PT.Gramedia Pustaka Utama.

Luthans, Fred. 2006. Perilaku Organisasi. (Alih Bahasa V.A Yuwono, dkk), Edisi Bahasa Indonesia, Yogyakarta: ANDI.

Mangkunegara, 2007. Evaluasi Kinerja, Bandung: PT. Refika Aditama.
Mangkunegara, 2009. Manajemen Sumber Daya Manusia, PT Remaja Rosdakarya: Bandung. Mangkunegara, Anwar Prabu. 2011. Evaluasi Kinerja SDM. Bandung: Remaja Rosda Karya.

Mangkunegara, Anwar Prabu, 2013. Manajemen Sumber Daya Manusia, Bandung: Remaja Rosdakarya.

Notoadmodjo, 2009, Pengembangan Sumber Daya Manusia, Jakarta: Rineka Cipta.

Panggabean, 2004. Manajemen Sumber Daya Manusia, Jakarta: Ghalia Indonesia.

Rivai \& Ella Jauvani, 2009. Manajemen Sumber Daya Manusia Untuk Perusahaan, Edisi Kedua, Jakarta: PT. Remaja Grafindo Persada.

Rivai, Veithzal dan Ahmad Fawzi Mohd Basri. 2005. Performance Appraisal. Cetakan Pertama. Jakarta: PT Raja Grafindo Persada.

Rivai, Veithzal. 2005. Evaluasi Kinerja. Bandung: Refika Utama.

Robbins, Stephen. 2008. Perilaku Organisasi. Terjemahan: Benyamin Molan. New Jersey: Prentice Hall, Inc.

Sedarmayanti. 2007. Sumber Daya Manusia dan Produktivitas Kerja. Bandung: CV. Mandar Maju. 
Subarsono, A. G. 2005. Analisis

Kebijakan Publik (Konsep,

Teori dan Aplikasi).

Yogyakarta: Pustaka Pelajar.

Sugiyono. 2010. Metode Penelitian Administrasi dilengkapi dengan Metode $R$ \& $D$, Bandung: Alfabeta.

Siagian, Sondang P, 2002. Kiat Meningkatkan Produktivitas Kerja, Asdi Mahasatya: Jakarta.

Sutrisno, Edy, 2012. Manajemen Sumber Daya Manusia. Jakarta: Kencana.

Sutrisno, Edy, 2014. Manajemen Sumber Daya Manusia. Jakarta: Kencana Prenada Media Group.

Timpe, A Dale. 2004. Seri Manajemen Sumber Daya Manusia (Kineja/ Performance, Cet. 4. Jakarta: PT Elek Media Komputindo.

Wibowo. 2007. Manajemen Kinerja. Jakarta: PT. Rajagrafindo Persada.

Yani, M., 2012, Manajemen Sumber Daya Manusia, Jakarta: Mitra Wacana Media. 